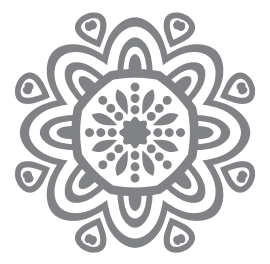

\title{
KONSEP KHAUF DALAM TAFSIR AL - MISBAH Telaah Atas Pokok-Pokok Pikiran Tasawuf M. Quraish Shihab
}

\author{
I k rar \\ Dosen IAIN Manado
}

\begin{abstract}
Khauf is a concept that usually exists in Tasawwuf. Khauf is usually coupled with rajâ'. Khauf and rajâ' 'are two concepts that describe God's relationship with humans. On the one hand, humans are afraid of God, but on the other hand humans have no place of hope other than Allah. On the one hand, humans are afraid of the effects of their sins that are not forgiven by God, but on the other hand humans have no place to beg forgiveness except to God. God is feared as well as expected. This study traces the meaning of khauf in the Al-Quran, especially the meaning of khauf according to M. Quraish Shihab in his work, Tafsir Al-Mishbah. This study found the typical way of M. Quraish Shihab in interpreting the Al-Quran, namely connecting the word khauf with the context of the sentence or verse where the word khauf was mentioned. One important finding of this study is that according to M. Quraish Shihab, the word khauf in the Al-Quran is always coupled with the word rabb. Rabb means keeper or educator. Therefore, $M$. Quraish Shihab emphasized that the meaning of khauf must not be separated from the meaning of rabb or the fear of humans to God must be within the framework of Godss care and education of humans.
\end{abstract}

Keywords: khauf, rabb, M. Quraish Shihab

\section{PENDAHULUAN}

\section{A. Latar Belakang Masalah}

Al-Qur'an al-Karim apabila dicermati terutama dalam memerhatikan pemberian petunjuk kepada manusia untuk menuju iman yang benar dan pri- 
laku yang berbudi, juga memberikan pandangan berharga tentang manusia dan sifat-sifatnya. Walaupun demikian Al-Qur'an tidak hanya memusatkan perhatiannya pada aspek fisik dan biologis manusia; atau paling tidak aspek ini bukan merupakan perhatian utama Al-Qur'an. Tabiat psychic (jiwa) Manusialah menyangkut aspek sosial, moral dan spiritual, yang membentuk tema sentral wacana Al-Qur.an tentang manusia. ${ }^{1}$

Din al-Islam atau ajaran penutup yang dibawa oleh Nabi Muhammad Saw., menurut Muhammad Yusuf Qardhawi, mencakup beberapa hal yaitu:

1. Kepercayaan-kepercayaan yang benar, yang membenarkan pandangan manusia terhadap al-Wujud, kepada pencipta dan makhluk-Nya, meliputi manusia, alam, kehidupan dan kematian, dunia dan akhirat. Dan menjernihkan kepercayaan yang berdasarkan imajinasi akal manusia.

2. Ajaran yang abadi tersebut mencakup ibadah ritual-ritual yang telah diwajibkan Allah pada hamba-hamba-Nya yang memeluk agama Islam.

3. Ajaran tersebut juga mencakup nilai-nilai moralitas dan keutamaan-keutamaan mulia yang dapat mengangkat derajat manusia dan mendapat derajat yang tinggi, serta membedakan manusia dari hewan dan binatang serta makhluk lainnya. ${ }^{2}$

Bias dari Praktek keberagamaan seseorang tentu dipengaruhi oleh pemahamannya terhadap dua sumber ajaran Islam di atas. Karena itu, para pakar mencoba memberikan alternative-solusi untuk melihat aspek-aspek ajaran yang terdapat dalam dua sumber tersebut. Sebagai contoh, Harun Nasution, Latihan spiritual, dan ajaran moral; aspek sejarah dan kebudayaan; aspek politik; aspek hukum; aspek teologi; aspek mistisisme; dan aspek pembaharuan. ${ }^{3}$

Akhir-akhir ini, terdapat kecenderungan masyarakat, terutama, masyarakat kota, untuk mengisi aktivitasnya dengan aktivitas yang bernuansa agama atau spiritual. Hal ini, terlihat dari maraknya tayangan televisi yang bernuansa rohani dan mistis. Boleh jadi, hal ini disebabkan oleh kejenuhan mereka terhadap kehidupan yang terlalu banyak dipenuhi warna-warni dunia yang bernuansa materi belaka yang terkadang mengenyampingkan akhirat dan nilai-nilai spiritual bahkan moral.

${ }^{1}$ Zafar Afar Anshari, Qur'anic Concepts of Human Psich, Diterjemahkan oleh Abdullah Ali, Al-Quran Bicara Tentang Jiwa, (Jakarta : Arasy, 2003), hal. 1.

${ }^{2}$ Yusuf Qardhawi, Fiqhi Minoritas Fatwa Kontemporer terhadap kehidupan Kaum Muslimin di Tengah Masyarakat Non Muslim, Jakarta : Zikrul Hakim, 2004, hal.3-4.

${ }^{3}$ Harun Nasution, Islam Ditinjau Dari Berbagai Aspeknya, Jilid I,II, Jakarta: Bulan Bintang,1994, hal.26. 
Oleh karena itu, suatu hal yang dapat dimaklumi jika akhirnya mereka lari kepada prilaku spiritual atau agama. Sebab dengan prilaku spiritual tersebut, sebagaimana disebutkan Emil Durkheim, seorang pakar sosiologi, bahwa pada hekekatnya manusia dapat melakukan penyucian, karena agama merupakan penyucian tradisi, yang menyangkut kebutuhan-kebutuhan masyarakat dalam prilaku masyarakat atas tumpuan akhir kecenderungan masyarakat tersebut. Oleh sebab itu, dengan prilaku spiritual tersebut, mereka memperoleh rasa nyaman dan merasa di dalam dirinya memiliki lebih banyak tenaga, baik untuk menjalani hidup dalam menaklukkan tantangan hidup. ${ }^{4}$

Dari sini kemudian, marak muncul berbagai aliran atau pengajian serta majelis-majelis yang bernuansa rohanai serta prilaku tasawuf akibat dari jawaban atas kekerasan mereka. Sebagaimana diungkapkan oleh A'sad El-Hafidy bahwa aliran-aliran agama yang bercorak kebatinan timbul sebagai reaksi terhadap kondisi yang dianggap bertentangan dengan norma, sehingga mereka ingin mencari ketenangan jiwa atau ingin mengembalikan kepada ajaran aslinya, dengan menyendiri menjauhi keramaian, dan sebagainya. Sebab pasca kemajuan ilmu pengetahuan dan tekhnologi mencapai puncaknya, masyarakat mulai merasakan kekosongan jiwa. Sikap masyarakat yang sekuler dan materialistis, akibat pengaruh sains dan tekhnologi yang disalah gunakan sehingga membawa dampak pada kerusakan lingkungan alam, kecemasan dan ketakutan yang selalu meliputi umat manusia. Pencapaian meteri yang berlimpah ternyata tidak selelu membawa kebahagiaan yang pasti bagi kehidupan manusia yang senantiasa dicari-cari. $^{5}$

Dengan kata lain, mengutip ungkapan Thomas F. "Odea, dengan prilaku spiritual manusia akan memperoleh dua hal yaitu: pertama,memperolah cakrawala pandang tentang dunia luar yang tak terjangkau oleh manusia. Dan ke$d u a$, memperoleh sarana yang memungkinkan hubungan antara dirinya dengan sesuatu hal diluar jangkauannya, yang memberikan jaminan dan keselamatan bagi manusia. ${ }^{6}$

Bila ditinjau dari sudut pandang bahwa Al-Quran penuh dengan gambaran dan anjuran hidup secara sufi, maka Al-Quran merupakan sumber pertama dari ajaran dan praktek tasawuf. Ini juga menunjukkan bahwa Al-Quran standar dari cara hidup atau praktek para suf. Hampir semua konsep-konsep dalam

\footnotetext{
${ }^{4}$ Thomas F. 'Odea, Sosiologi Agama;Suatu Pengenalan Awal, Penerjemahan Yasogama, Jakarta: Rajawali Press, 1996, hal. 22.

${ }^{5}$ As'ad El-Haridi, Aliran-Aliran Kepercayaan Dan Kebatinan Di Indonesia,Jakarta: Ghalia Indonesia, 1997) hal. 95.

${ }^{6}$ Thomas F. 'Odea, Sosiologi Agama;Suatu Pengenalan Awal,... hal. 25.
} 
tasawuf berasal dari Al-Qur'an. Konsep-konsep maqamat," seperti tobat, sabar, tawakal, ridha, dan sebagainya. Semuanya di ambil dari Al-Quran. Demikian juga halnya konsep-konsep yang berkaitan dengan ahwal ${ }^{8}$ Seperti mahabbah, khauf, raja', thuma'ninah, yaqin, dan sebagainya. Konsep-konsep kejiwaan yang akrab beredar di kalangan para sufi pun berasal dari Al-Qur'an seperti nafsu alammarah, nafsu al-lawwamah,nafsu al-muthmainnah. Semua itu jelas menunjukkan bahwa tasawuf bersumber dari Al-Qur'an. ${ }^{9}$

Merupakan satu hal yang menarik tentunya, jika konsep-konsep yang dianggap sebagai konsep dalam dunia tasawuf dikaji melalui pendekatan AlQur’an, dalam hal ini melalui kajian tafsir. Hingga saat ini, masih sangat jarang sekali tafsir-tafsir Al-Qur'an yang memakai pendekatan tasawuf bahkan bisa dikatakan tidak ada. Yang terkenal di Indonesia barulah tafsir al-Azhar milik Hamka yang bernuansa tasawuf.

Oleh karena itu, makalah ini hendak mengkaji pemahaman sufistik seorang tokoh yang sangat berpengaruh di Indenesia bahkan Asia Tenggara, dalam memahami ayat-ayat Al-Qur'an yang dijadikan patron dalam pengalaman spiritual para sufi, khususnya tentang konsep khauf.

Merujuk pada Al-Qur'an yang banyak berbicara tentang khauf yang menjadi landasan bagi para sufi untuk dapat sampai dan dekat pada Tuhan. Di dalam Al-Qur'an banyak ditemukan ayat-ayat yang berbicara tentang masalah ini, salah satu contoh dalam Al-Qur'an ialah Q.S. al-Nahl(16): 50, berbicara tentang keadaan orang-orang yang takut kepada Tuhan apabila mereka tidak melaksanakan apa yang diperintahkan kepada mereka. Lihat Q.S. al-Nur(24):

\footnotetext{
${ }^{7}$ Maqamat (station) adalah bentuk jamak dari maqam secara literal tempat berdiri, station, lokasi, posisi,atau tingkatan. Secara estimologis berarti kedudukan spiritual seseorang. Dan secara terminilogis banyak pendapat para ulama yang berbeda-beda, salah satunya pendapat al-Hujwiri yaitu maqam adalah "keberadaan seseorang di jalan Allah, yang dipenuhi olehnya kewajiban-kewajiban yang berkaitan dengan maqam itu serta menjaga hingga ia mencapai kesumpurnaannya, sejauh berada dalam kekuatan manusia. Media zainul Bahri, menembus tirai kesendirian-Nya Mengurai maqamat dan Ahwal dalam Tradisi sufi, Jakarta Pranada2005, hal. 32. lihat juga al-Hujrawi. Kasy; ful mahjub; Risalah tertua Tentang tasawuf, Terjemahan Abd Hadi WM., Bandung Mizan, 1973, hal.170.

${ }^{8}$ Ahwal (state) adalah bentuk jamak dari hal. Seperti halnya maqam, hal ini digunakan kaum sufi untuk menunjukkan kondisi spiritual. Kata hal dalam perspektif tasawuf sering diartikan dengan "keadaan", yang menjadi hakikat kenabian sebagaimana sabda Nabi Saw, "syariah adalah perkataan-perkataanku (aqwali), tariqah adalah perbuatan-perbuatanku (amali) dan haqiqah adalah keadaan-keadaan batinku (ahwali)". Lihat Annimare Schimel, Dimensi Mistik Dalam Islam, terjemah Sapardi Djoko Damono Dkk., Jakarta: Pustaka Firdaus,2000, hal. 123. berbeda dengan maqam, untuk mencapai hal tidak menggunakan usaha (makasib) tetapi merupakan karunia (mawahib).Media Zainul Bahri, menembus tirai kesendirian-Nya Mengurai maqamat dan Ahwal dalam Tradisi sufi, hal. 37-38.

${ }^{9}$ Media Zainul Bahri, Menembus Tirai Kesendirian-Nya Mengurai Maqamat dan Ahwal dalam Tradisi sufi, hal. 1-2.
} 
37, berbicara tentang keadaan orang-orang yang takut akan hari kiamat karena mengetahui betapa dahsyatnya hari itu. Hal ini dapat dilihat pada Q.S. al-Rahman(55):46,menceritakan tentang kedudukan orang-orang yang takut kepada Tuhan akan mendapatkan dua surga baginya.

M. Quraish Shihab menganggap bahwa khauf sebagai gejala awal munculnya agama dan prilaku agama, terutama dalam hal amal-amal shaleh. Ia merupakan gejala yang sangat vital bagi permasalahan hidup manusia. Khauf dapat menjadi suatu yang sangat berguna jika ia berada pada posisi yang benar dan dapat menghasilkan perbuatan-perbuatan yang positif, akan tetapi dapat menjadi sesuatu yang sangat berbahaya, jika berada pada posisi yang salah dan mempunyai pengaruh negative bagi jiwa dan prilaku seseorang. ${ }^{10}$

Berdasarkan pada contoh ayat-ayat di atas, maka makalah ini hendak mengungkapkan pemahaman tentang konsep khauf dari seorang ulama/pakar tafsir M. Quraish Shihab dalam kitab tafsirnya al-Misbah.

\section{B. Rumusan masalah}

Berdasarkan gambaran dari latar belakang di atas, penulis akan mengemukakan Identifikasi permasalahan sebagai berikut:

1. Bagaiamana Biografi dan Intelektualitas M. Quraish Shihab?

2. Bagaimana pokok-pokok pikiran Tasawuf M. Quraish Shihab terhadap konsep khauf dalam tafsir al-Misbah."?

3. Bagaiamana Pandangan M. Quraish Shihab tentang konsep Khauf Dalam Tafsir Al-Misbah?

\section{PEMBAHASAN}

\section{A. Biografi Singkat M. Quraish Shihab}

M. Quraish Shihab lahir di Rappang, Sulawesi Selatan pada Tgl 16 Februari 1944. Pendidikan dasarnya diselesaikan di ujung pandang (Makassar Sekarang), Kemudian melanjutkan Pendidikan Menengahnya di Malang (Jawa Timur) Sambil "nyantri di pondok Pesantren Darul-Hadis al-Fiqhiyah. ${ }^{11}$ Ia berasal dari keturunan Arab yang terpelajar.Ibunya bernama Asma Aburisyi dan dan bernama ayahnya Abdurahman Shihab (1905-1986) Ayahnya adalah lulusan Ja-

${ }^{10}$ M. Quraish Shihab, Logika Agama: Kedudukan Wahyu dan Batas-Batas Akal dalam Islam, Jakarta: Lentera Hati, 2005, hal. 30.

${ }^{11}$ Lihat" tentang penulis" Dalam M. Quraish Shihab, Membumikan Al-Qur'an Fungsi dan Peran Wahyu dalam Kehidupan, Bandung: Mizan1994, hal. 4. 
miatul Khair Jakarta, sebuah lembaga pendididkan tertua di Indonesia yang mengedepankan gagasan Islam modern. Ayahnya, selain sebagai guru Besar dalam bidang tafsir, juga pernah mendududki jabatan Rektor IAIN Alauddin Ujung Pandang Pada Tahun 1972-1977) (UIN Makassar Sekarang), dan tercatat sebagai seorang pendiri universitas Muslim Indonesia (UMI) di Ujung Pandang (Makassar). ${ }^{12}$ Selain sebagai seorang Ilmuan ia Juga sebagai seorang Da’i, ia adalah seorang pengusha

Sejak kecil M. Quraish Shihab telah menjalani pergumulannya dengan Al-Quran, yang telah menumbuhkan kecintaannya terhadap terhadap AlQur'an, Ayahnya adalah orang yang paling berperan dalam hal ini. Pada umur 6-7 tahun oleh ayahnya, ia harus mengikuti pengajian yang telah diadakan oleh ayahnya sendiri. Pada waktu itu selain menyuruh membaca al-Qur'an ayahnya juga menguraikan secara sepintas kisah-kisah dalam Al-Qur'an. Dari snilah awal munculnya benih-benih kecintaannya terhadap Al-Qur'an dan Studi Al-Qur'an mulai tumbuh dan berkembang. ${ }^{13}$

Ketika M. Quraish Shihab akan belajar di Universitas Al-Azhar pada Tahun 1958 atas bantuan beasiswa dari pemerintah daerah Sulawesi (waktu itu wilayah Sulawesi belum di bagi : menjadi : Sulawesi Utara, Sulawesi Selatan, Sulawesi Tengah dan Sulawesi Tenggara), Terhitung Sembilan Tahun kemudian, yaitu tepatnya pada tahun 1967, ia telah merai gelar Lc (SI) pada Fakultas Ushuluddin jurusan Tafsir Hadis Universitas Al-Azhar Kairo. Kemudia melanjutkan Studinya di fakultas yang sama dan pada tahun 1969 ia meraih gelar MA (Master Of Arch) untuk spesialisasi bidang Tafsir Al-Qur'an dengan tesis yang berjudul “Al-I'jaz al-Tasyri'iy li Al-Qur'an al-Karim."14

Pada Tahun 1980, M. Quraish Shihab kembali ke Kairo Mesir dan melanjutkan pendidikannya pada jenjang S3 (Program Doktor) di almamater yang sama, (Universitas Al-Azhar Kairo), dan pada tahun 1982, dengan disertasi yang berjudul "Nazm al-Durar li al-Biqa'iy, Tahqiq Wa Dirasah" dia berhasil meraih gelar Doktor dalam Bidang Ilmu-ilmu Al-Qur’an dengan yudisium Summa Cum Laude disertai penghargaan tingkat I (Mumtaz Ma'a martabat al-syarfal-ula) ${ }^{15}$. Ia orang pertama di Asia Tenggara yang meraih gelar Doktor dalam ilmu-ilmu Al-Quran di Universitas Al-Azhar. ${ }^{16}$

${ }^{12}$ Islah Gusmian, Kazanah Tafsir Indonesia: dari hermenetika hingga Ideologi Bandung : Teraju, 2003, hal. 80 .

${ }^{13}$ M. Quraish Shihab, Membumikan Al-Qur'an,... hal. 14.

${ }^{14}$ M. Quraish Shihab, Membumikan Al-Qur'an,... hal. 4, 14.

${ }^{15}$ M. Quraish Shihab, Membumikan Al-Qur'an,... hal. 4.

${ }^{16}$ Islah Gusmian, Khazanah Tafsir Indonesia, .... hal.81. 
Pada saat M. Quraish Shihab kembali ke Indonesia setelah memperoleh gelar Doktor di universitas Al-Azhar Kairo pada tahun 1984 ia ditugaskan di Fakult5as Ushuluddin dan Fakultas Fasca Sarjana IAIN Syarif Hidayatullah, Jakarta. ${ }^{17}$ Pada tahun 1992-1998 ia perna menjadi Rektor IAIN yang sekarang menjadi UIN Syarif Hidayatullah Jakarta. ${ }^{18}$ Selain itu pada tahun yang sama ia juga diangkat sebagai Duta Besar RI Untuk Mesir, Jubouti, Somalia. Dan Pada Tahun 1999 dipilih sebagai anggota Dewan riset Nasional. ${ }^{19}$ Pernah mengikuti pelatihan Strategic Management Selama 10 minggu Ambersdi wilayah Massachussets Amerika Serikat. ${ }^{20}$

Berdasarkan pengakuan M. Quraish Shihab dalam salah satu tulisannya, ada dua tokoh yang sangat berpengaruh dalam kehidupan keberagamaan dan keilmuannaya, disamping ayah da ibunya. Kedua orang tersebut selalu menjadi inspirasi dalam hidupnya. Yang pertama adalah Al-Habib Abdul Qadir (Wafat di Malang 1962 dalam usia 65 tahun) beliu adalah guru dan mursid-nya di Pesantren Dar al-Hadis al-Fiqhiyah Malang, sejak tahun 1956-1958 dan beliau yang memperkenalkannya pertama kali dalam dunia sufistik, dan yang mengingatkannya untuk selalu menggandengkan nama "Muhammad setiap kali menyebut atau menulis namanya. Al-Habib berpesan, jangan pisahkan namamu dari Muhammad, sebutlah selalu dengan sebutan "M. Quraish Shihab". Kedua adalah syekh Abdul Halim Mahmud, (1910-1978)M) yang juga digelari dengan "Imam al-Gazali abad XIV H”. Beliau adalah Imam al-Akbar, yakni pemimpin tertinggi lembaga-lembaga al-Azhar. Beliau termasuk praktisi tasawuf yang sangat mengagumi Imam al-Gazali. ${ }^{21}$

Dari Kedua tokoh tersebut, M. Quraish Shihab sedikit banyak telah bersentuhan dengan dunia tasawuf, walaupun secara praktis ia bukanlah praktisi Tasawuf seperti gurunya. Tetapi setidaknya, benih-benih tasawuf sedikit banyaknya mempengaruhi kehidupannya. Ia belajar dari keduanya tentang makna taqwa, keikhlasan dan kezuhudan atau kesederhanaan.

\section{B. Karya-karya M. Quraish Shihab}

M. Quraish Shihab termasuk seorang penulis yang sangat produktif. Hal ini dapat dilihat dari hasil-hasil karyanya yang monumental dan telah dipub-

${ }^{17}$ M. Quraish Shihab, Membumikan Al-Qur'an,... hal. 14.

${ }^{18}$ Lihat Biografi Penulis Pada sampul buku, dalam M. Quraish Shihab, Menabur Pesan Ilahi; Al-Quran Dan dinamika Kehidupan Masyarakat, Jakarta : Lentera Hati, 2006 .hal. 4.

${ }^{19}$ Biografi Penulis dalam M. Quraish Shihab, Menabur Pesan Ilahi,... hal. 14.

20 "Sekapur Sirih" Dalam M. Quraish Shihab, Mukjizat Al-Qur'an; Ditinjau dari aspek Kebahasaan, Isyarat Ilmiah, dan Pemberitaan Gaib Bandung; Mizan, 2002, hal. 8-9.

${ }^{21}$ M. Quraish Shihab, Logika Agama,...hal. 20-24. 
likasikan. Hingga saat ini, terhitung 26 karya-karya intelektualnya yang telah diterbitkan yang penulis dapatkan datanya yaitu:

1. Kajian tentang "Tafsir Al-Manar: Keistimewaan dan Kelemahannya, (Ujung Pandang IAIN Alauddi, 1984).

2. Membumikan Al-Quran: Funsi dan peran Wahyu dalam Kehidupan Masyarakat (Bandung Mizan 1994).

3. Lentera Hati, Kisah dan Hikmah Kehidupan, (Bandung: MIzan, 1994).

4. Wawasan Al-Qur'an, Tafsir Maudhu'.i atas Pelbagai Persoalan Umat, (Bandung : Mizan 1996).

5. Tafsir Al-Quran Al-Karim: Tafsir atas surah-surah pendek Berdasarkan Urutan Turunnya Wahyu (Bandung: Pustaka Hidayah, 1997).

6. Buku tersebut juga diterbitkan kembali dengan judul : Tafsir Surah-Surah Pendek, ( Jakarta : Lentera Hati, 2006).

7. Untaian Permata Buat Anakku, (Bandung: Mizan, 1998).

8. Mukjizat Al-Quran:Ditinjau dari aspek Kebahasaan, Isyarat Ilmiah dan Pemberitaan Gaib, (Bandung MIzan, 199),

9. Menyingkap Tabir Ilahi, (Jakarta: Lentera Hati, 1998).

10. Yang Tersembunyi: Jin, Iblis, Setan Malaikat, ( Jakarta: Lentera Hati, 1999),

11. Pengantin Al-Qur,an, (Jakarta: Lentera Hati 1999).

12. Haji Bersama M. Quraish Shihab,( Bandung Mizan,1999).

13. Sahur Bersama M. Quraish Shihab,(Bandung: Mizan, 1999).

14. Shalat Bersama M. Quraish Shihab, (Jakarta Abdi Bangsa).

15. Puasa Bersama M. Quraish Shihab, (Jakarta Abdi Bangsa).

16. Fatwa-fatwa M. Quraish Shihab, (Bandung Mizan, 1999), 4 jilid.

17. Hidangan Ilahi Tafsir Ayat-Ayat Tahlil, (Jakarta Lentera Hati, 1999).

18. Perjalanan Menuju Keabadian: Kematian, Surga dan Ayat-ayat Tahlil. (Jakarta: Lentera Hati, 2000).

19. Menjemput Maut; Berkat Perjalanan Menuju Allah Swt. (Jakarta: Lentera Hati, 2002),

20. Tafsir Al-Misbah: Pesan dan Kesan Keserasian Al-Qur'an, (Jakarta : Lentera Hati, 2003),Jumlanya 15 jilid Buku tersebut ditulis di Kairo pada tanggal 18 Juni 1999. Dari segi bentuk kemasannya buku Tafsir al-Misbah ditulis secara berseri, terdiri dari beberapa volume hngga 30 juz. Model cetakannya ada dua bentuk : dicetak dalam tampilan biasa dan dalam tampilan lix dengan Hard-Cover. Uraian di dalamnya banyak merujuk kepada Al-Qur'an 
dan Sunnah dengan menggunakan model penyajian Tahlili dan analisis atas kosa kata yang menjadi kata kunci. Di dalan buku tersebut aplikasi keilmuan M. Quraish Shihabsebagai seorang pakar Tafsir dan Ulumul Quran.

21. Jilbab Pakaian Wanita Muslimah: dalam Pendangan Ulama Klasik dan Cendekiawan Kontemporer, (Jakarta : Lentera Hati, 2004)

22. Dia di Mana-Mana: Tangan Tuhan Dibalik Setiap Penomena, (Jakarta : Lentera Hati, 2004).

23. Perempuan: Dari Cinta Sampai Seks, dari Nikah Mut'ah Samapai nikah sunnah dari Bias Lama Sampai Bias Baru. (Jakarta: Lentera Hati, 2005).

24. Logika Agama: Kedudukan Wahyu dan Batas-Batas Akal dalam Islam,(Jakarta: Lentera Hati, 2005),

25. Menabur Pesan Ilahi: Al_Qur'an dan Dinamika Kehidupan Masyarakat, (Jakarta: Lentera Hati, 2006)..

26. Kaidah Tafsir (Syarat, Ketentuan, dan Aturannyang patutanda Ketahui dalam memahami ayat-ayat al-Qur'an). Dilengkapi Penjelsan Kritis Tentang Hermenetika dalam Penafsiran Al-Qur'an (Lentera hati 2013). ${ }^{22}$

\section{Pengertian Khauf}

Kata Khauf berasal dari kata kha waw dan fa yang menunjuk kepada maknaketakutan dan keterkejutan. Dan kalau dilatakan "aku takut kepada si pulan," maka itu adalah benar-benar takut kepadanya (Asayaddul Khauf). ${ }^{23}$ Khauf juga seakar kata dengan kata Khaafa, Yakhafu Khaufan yang berarti takut (Al-Zairu), terkejut (Al-Faz'u), ${ }^{24}$ tidak aman dan khawatir (Dhaddul Amnu), ${ }^{25}$ dan Pengetahuan (Al-Ilmu). ${ }^{26}$ Khawafa al-Rajulu, artinya Lelaki itu membuat orang lain takut kepdanya. Di dalam Al-Qur'an, Allah Swt. Berfirman pada QS. Ali Imran(3): 175 :

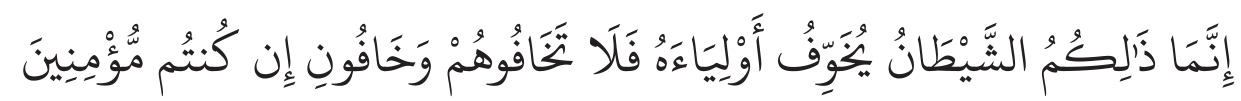

${ }_{22}$ M. Quraish Shihab, Logika Agama: Kedudkan Wahyu dan Batas-batas Akal dalam Islam,....hal. 9-10

${ }^{23}$ Abi Al-Husain Ahmad bin Faris bin Zakaria, Al-Mu'jam Maqayis al-lugah, Juz I, Kairo Dar Al-Fikr, 395 H, hal. 230.

${ }^{24}$ Muhammad Idris Al-Marbawi, Kamus Idris al-Marbawiy; Arab Melayu, Kairo Dar alFikr. T.tp, t.th., hal. 191.

${ }^{25}$ Muhammad Idris Al-Marbawi, Kamus Idris al-Marbawiy; Arab Melayu,... hal. 191.

${ }^{26}$ Ahmad Warson Munawir, Al-Munawwir, Kamus Arab Indonesia, Jakarta: Pustaka Progresif, 1984, hal. 406. 
Sesungguhnya mereka itu tidak lain hanyalah syaitan yang menakut-nakuti (kamu) dengan kawan-kawannya (orang-orang musyrik Quraisy), karena itu janganlah kamu takut kepada mereka, tetapi takutlah kepada$\mathrm{Ku}$, jika kamu benar-benar orang yang beriman. ${ }^{27}$

Adapun kebalikan dari khauf adalah rasa aman, ia dapat digunakan dalam urusan dunia dan akhirat, timbul akibat memprediksikan terjadinya hal yang tidak disukai perasaan ini menimbulkan hati yang bersangkutan menjadi bergetar, tidak menentu gerakannya atau terkejut terhadap hal yang tidak disukai, baik karena akan terjadinya hal yang tidak disukai. ${ }^{28}$ Secara keseluruhan al-Ashfahani menganggap bahwa khaufitu bersifat naluriyah, ia selalu mendampingi manusia kapan dan dimana saja berada.

Apa yang dikemukakan oleh al-Ashfahani di atas, jelas bahwa khaufberada pada tataran rasa. Oleh karena itu, khauf dapat dimaknai sebgai kegalauan hati membayangkan sesuatu yang tidak disukai yang akan menimpanya, atau membayangkan hilangnya sesuatu yang disukainya ( faza al-qalb min makruhu yunaaluhu aw mahbub yafutuh ). ${ }^{29}$

Rasa takut atau khauf, sebagaimana di jelaskan di atas, merupakan suatu hal yang manusiawi, sebab manusia tidak dapat menjamin dirinya selalu selamat dan aman dari sesuatu yang dapat membinasakan di masa yang akan datang.

Imam Al-Gazali menjelaskan bahwa rasa takut itu muncul karena ada pengetahuan tentang sesuatu yang ditakuti tersebut. Oleh karena itu, menurutnya ilmu adalah sebab yang membawa manusia merasa takut kepada sesuatu yang tidak disukai. Dia memberikan contoh, seperti orang yang berbuat aniaya terhadap raja, kenudian ia tertangkap oleh raja. Ia takut kalau-kalau akan medapatkan hukuman yang berat dari raja, seperti dibunuh, digantung, atau dipenggal lehernya, karena ia tahu sifat yang dimiliki oleh sang raja sedang murka. ${ }^{30}$

Al-Gazali lebih jauh menambahkan bahwa kadang-kadang takut tidak disebabkan oleh kejahatan yang dilakukan melainkan justru dari sifat yang menakutukan itu sendiri, seperti takut diterkam oleh binatang buas, bukan karena binatangnya, melainkan karena sifat kebuasan binatang tersebut. Dan terkadang pula takut itu disebabkan oleh sifat dan tabiat dari yang ditakuti. Seperti takut pada air, karena tabiat air dapat menenggelamkan dan juga dapat menghanyutkan. Demikian pula halnya takut pada api, karena tabiat api yang dapat membakar. ${ }^{31}$

\footnotetext{
${ }^{27}$ Departemen Agama RI,Al-Qur'an Terjemahnya,...hal. 106.

${ }^{28}$ Al-Raghib al-Asfahani, Al-Mufradat fi Gharib al-Qur'an, Kairoa: Dar al-Ma'rifah 2004, hal. 166.

29 Yanahar Ilyas, Kuliah Akhlak, Yogyakarta: Lembaga Pengkajian dan pengamalan Islam (LPPI), t.th, hal. 39.

30 Al-Gazali, Masalah Takut dan harapan Surabaya: Mahkota, 1986, hal. 74-75. Bandingkan dengan Ibnu Qudamah, Mukhtasar Minhajul Qashidin; Jalan orang-orang yang mendapat petunjuk Jakarta Pustaka al-Kautsar, 1997, hal. 387-388.

31 Al-Gazali, Masalah Takut dan harapan,...,hal. 74-7.
} 
Sejalan dengan pendapat al-Ashfahani, Abul Qasim al-Hakim berpendapat bahwa takut kepada sesuatu adalah berlari darinya dan takut kepada Allah Swt. Adalah berlari kepada Allah Swt. Yakni bertambah dekat kepada-Nya dengan maningkatkan ketaatan kepada-Nya. ${ }^{32}$ Pendapat yang senada dikemukakan oleh Ahmad al-Nuri ${ }^{33}$ bahwa seorang yang takut adalah yang lari dari Tuhannya untuk menuju kepada Tuhannya.

Rasa takut kepada Allah Swt. Didasari atas pengenalan diri yang mantap kepada Allah Swt. Seseorang jika semakin kenal kepada dirinya sendiri semakin takut kepada Allah Swt. ${ }^{34}$

\section{Macam-macam khauf}

Menurut Ibnu Qudamah, rasa takut itu ada tiga macam : Pertama, rasa takut yang berlebihan, yaitu rasa takut yang melebihi batas kewajaran hingga bisa menjerumuskan kepada keputus asaan. Rasa takut seperti itu adalah rasa takut tercela atau negativ, karena yang demikian bias membuatnya sakit, stress, dan bahkan bisa menyebabkan kematian. ${ }^{35}$ Banyaknya kasus bunuh diri atau pembunuhan terhadap anak karena terjadinya rasa takut yang seperti itu. Kedua, rasa takut yang diremehkan atau kurangnya rasa takut. Rasa takut yang demikian juga adalah termasuk rasa takut yang negativ, Ia diibaratkan sebuah lidi yang digunakan untuk memukul hewan yang besar, tentu tidak bisa membuat hewan tersebut merasa kesakitan, tidak mampu menuntunnya kepad sesuaut yang dimaksudkan dan tidak bias digunakan untuk melatihnya. ${ }^{36} \mathrm{Hal}$ inilah yang sering menghinggapi manusia pada umumnya, sehingga seringkali membuatnya lalai. Ketiga, rasa takut yang sedang (pertengahan) inilah takut yang terpuji atau takut positif. Diibaratkan seorang hamba Allah Swt. yang takut melanggar ketentuan Allah Swt. Misalnya takut melalaikan shalat lima waktu walau hanya sekali saja. ${ }^{37}$

Dari Uraian di atas, dapat dipahami bahwa khauf atau takut tidak selalu baik (positif) tetapi khauf juga terkadang malah menjadi buruk (negativ) apabila berada pada posisi yang keliru dan salah. Untuk lebih mehami tentang konsep khauf, maka akan dijelaskan tentang khauf yang baik (positif) dan khauf buruk (negativ). Adapu urainnya sebagai berikut :

32 Asmaran AS., Pengantar Studi Tasawwuf Jakarta:Raja Grafindo Persada, 2002 ,hal.142. Bandingkan dengan Media Zainul Bahri, Menembus Tirai Kesendirian-Nya,...hal.96.

33 Dia Adalah Abul Husain-Ahmad bin Muhammad al-Nuri Wafat 295H/908M, Lahir dan besar di Bagdad. Berguru kepada sari al-Sakathi Ibnu Abul hawari. Segenerasi dengan Al-Junaid RA. Dan dikenal sangat berbudi kuhur, dan baik dalam amaliah serta ucapan. Al-Qusyairi, Risalah Al-Qusyairiyah,... hal. 544.

34 Media Zainul Bahri, Menembus Tirai Kesendirian-Nya Mengurai Maqamat dan Ahwal dalam Tradisi sufi,....hal. 1-2.

\footnotetext{
${ }^{35}$ Ibnu Qudamah, Minhaj Al-Qashidin,....hal. 389.

${ }^{36}$ Ibnu Qudamah, Minhaj Al-Qashidin,,...hal. 389.

${ }^{37}$ Ibnu Qudamah, Minhaj Al-Qashidin,,...hal. 390.
} 


\section{Khauf Positif}

Ketakutan adalah sesuatu yang bersifat naluriah atau alamiah yang terdapat dalam diri manusia dan makhluk lain, seperti binatang. Ia merupakan suatu kewajaran selama berada pada tataran yang normal. Apabila rasa takut hilang pada diri manusia, maka dapat berakibat fatal, seseorang mungkin bisa saja tidak takut melompat dari gedung yang tinggi, bardiri di atas rel kereta api yang di atasnya kereta sedang berjalan dan lain sebagainaya. Ketiadaan rasa takut seperti ini malah merupakan sikap abnormal. Bahkan ia juga dapat berakibat buruk apabila rasa takut mengalahkan akal sehat dan menekan keberanian. ${ }^{38}$ Ketakuatan yang tidak beralasan dapat mengubur segala impian dan harapan, hidup tanpa semangat, bahkan hidup akan menjadi stagnan kerana takut melakukan sesuatu.

Takut dalam bentuknya yang murni, merupakan sesuatu yang alamiah dan bersifat naluriah yang memperingatkan seseorang dari bahaya dan kecelakaan yang akan menimpanya, laksana lampu merah dipersimpangan jalan. Ia dapat berfungsi sebagai peringatan untuk berhati-hati dalam bertindak melangkah.

Takut yang positif adalah takut yang wajar, yang mebuat seseorang berhati-hati misalnya menyeberang jalan yang ramaio dengan kendaraan, membuat seseorang berlindung di tempat yang aman ketika terjadi gempa, dan sebagainya. Takut posotif membuat orang waspada dengan perhitungan yang berdasarkan pada kenyataan-kenyataan yang riil. ${ }^{39}$ Dalam hal ini, takut positif yang dimaksud adalah takut kepada Allah Swt., bahkan takut kepada Allah Swt adalah sebagai takut yang wajib pada setiap orang yang beriman.

Didalam Al-Qur'an terdapat beberapa term-term yang semakna dengan khauf yang dapat dikategorikan sebagai takut yang positif dan sekaligus merupakan tahapan atau jenjang takut yang dimiliki oleh orang-orang yang takut kepada Allah Swt. Di antara khauf yang termasuk takut positif dalam Al-Qur'an ${ }^{40}$ adalah :

\footnotetext{
${ }^{38}$ Hamsah Ya’qub, Tingkat ketenangan dan kebahagiaan Mukmin; Tasawuf dan Taqarrub, Jakarta: Pustaka Atisa, 1992, hal. 129.

${ }^{39}$ Hamsah Yałub, Tingkat ketenagan dan kebahagiaan Mukmin; Tasawuf dan Taqarrub,... hal. 129.

${ }^{40}$ Rumusan ini berdasarkan term-term yang semakna dengan khauf dalam Al-Qur'an, seperti kata taqwa, khasya dan kata rahbah yang kesemuanya dapat diartikan sebagai takut. Lihat Misalnya tashiko Izutsu, Etico Religius Consepts in The Quran, Alih Bahasa oleh Fahri Huein at. al., dengan judul: Konsep Etika Religius dalam Al-Qur'an, Yogyakarta: Tiara Wacana Yogya, 1993, hal.235. Ada pula Ulama yang menambahkan seprti Abu Ali Daqqaq bahwa kata Haibah menyifati takut sebagai jenjang takut yang dimiliki oleh bseseorang yang takut kepada Allah. Lihat al-Qusyairi, Risalah Al-Qusyairiyah,...hal. 124.
} 


\section{a. Taqwa}

Kata Taqwa menurut bahasa terambil dari bentuk isim kata al-tuqa, sedangkan masdarnya adalah al-Ittiqa terambil dari asal kata waqa, waqya,wa waqayatan yang berarti menjaga atau melindungi ${ }^{41}$ atau sesuatu yang dijadikan sebagai sarana untuk menghindarkan diri dari sesuatu yang membahayakan. ${ }^{42}$ Dengan demikian al-wiqayah artinya pelindung sesuatu.

Devini taqwa banyak dijumpai dari berbagai referensi, dengan beragam pengertian. Al-Munajjid menyebutkan kurang lebih 13 bentuk devinisi taqwa. ${ }^{43}$ Semua devinisi yang dikemukakannya berindikasi pada ketakutan kepada Allah Swt. Baik terhadap siksa, ancaman, maupun karena keagungan-Nya. Salah satu di antaranya, taqwa ialah takut kepada Tuhan Yang Maha Mulia, mengamalkan wahyu yang diturunkannya, menerima dengan tulus rezeki yang sedikit, dan menjadikan bekal untuk hari yang akan datang ${ }^{44}$ (hari kemudian).

Di dalam al-Qur'an banyak ayat yang menyebutkan tentang taqwa, di antaranya Q.S. al-Hajj (22) :1 :

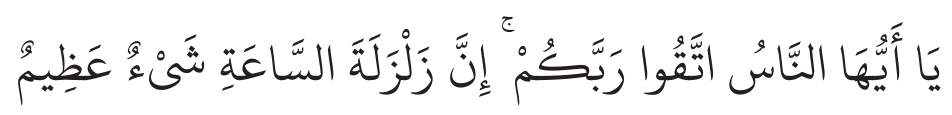

Hai manusia, bertakwalah kepada Tuhanmu; Sesungguhnya kegoncangan hari kiamat itu adalah suatu kejadian yang sangat besar (dahsyat). ${ }^{45}$

Kata taqwa juga terdapat pada Q.S. al-Baqarah (2) : 2 :

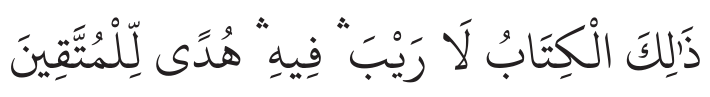

Kitab (Al Quran) ini tidak ada keraguan padanya; petunjuk bagi mereka yang bertaqwa. ${ }^{46}$

Kalau dikatakan bahwa taqwa adalah takut (dalam arti Khauf), maka ia bukanlah jenis ketakutan yang biasa, melainkan adalah bentuk takut yang paling sempurna. ${ }^{47}$

${ }^{41}$ Ahmad Munawwir, al-Munawwir,...hal. 1684.

${ }^{42}$ Al-Ragib Al-Asfahani, Al-Mufradat Fi Gharib al-Qur'an,... hal. 545.

${ }^{43}$ Muhammad bin Saleh al-Munajjid, Silsilah A'mal Al-Qulub, Alih Bahasa oleh Bahrun Abu bakar Ihzan Zubaidi, Lc.Bandung Irsyad Bait al-Salam (IBS), 2006, hal.580-585.

${ }^{44}$ Muhammad bin Saleh al-Munajjid, Silsilah A'mal Al-Qulub,... hal.580-585.

${ }^{45}$ Departemen Agama RI, Al-Quran dan Terjemahnya,...hal. 511.

${ }^{46}$ Departemen Agama RI, Al-Qur'an dan Terjemahnya,...hal. 8

${ }^{47}$ Tashihiko Izutsu, Etico Religious in the Qur,an... hal. 235. 


\section{b. Khasya}

Khasya diambil dari huruf Kha, Syin dan huruf mu,tal ( yaa) yang arinta menunjuk kepada ketakutan dan kepanikan (al-dzu'ru), Kemudian diletakkan atasnya majaz. Seperti kata perkataan Khasyaitu maka itu berarti majaznya adalah 'Alimtu. ${ }^{48}$

Al-Ashfahani juga mengartikan Khasyadengan takut yang menyerupai penta'ziman dan lebih apa uang mungkin dari ilmu dengan apa yang ditakuti darinya $^{49}$ dan khasya ini adalah khusus bagi para ulama Seperti yang terdapat dalam Q.S. Fathir (35) 28 :

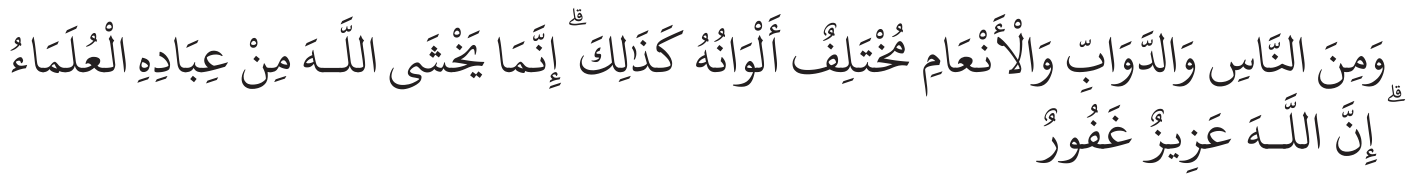

dan demikian (pula) di antara manusia, binatang-binatang melata dan binatang-binatang ternak ada yang bermacam-macam warnanya (dan jenisnya). Sesungguhnya yang takut kepada Allah di antara hamba-hamba-Nya, hanyalah ulama[1258]. Sesungguhnya Allah Maha Perkasa lagi Maha Pengampun. 50

Ayat tersebut menyebutkan bahwa ketakutan itu hanya dimiliki oleh para ulama yang berlandaskan pada pengetahuan dan pemahaman tentang kebesaran Allah Swt. Dengan demikian jelas pula perbedaan antara khauf dengan khasya. Khauf adalah jenis takut bagi kalangan awam dari orang-orang yang mengetahui kebesaran Allah Swt. Lebih tegasnya walaupun keduanya terbentuk dalam diri seseorang berdasarkan jangkauan wawasan ilmu dan pengetahuannya, namun dalam aflikasinya, khauf berbeda de3nga khasya. Sebab apabila seseorang dikecam oleh rasa khauf ia akan menghindar dan melarikan diri, berbeda dengan khasya maka pelakunya akan menghindar dengan berdasarkan pada ilmu pengetahuannya. ${ }^{51}$ Syekh Ibnu Utsaimin, mengatakan bahwa khasya adalah rasa takut yang berlandaskan pada ilmu pengetahuan tentang kebesaran Tuhan yang ditakuti karena kekuasaan-Nya Yang Maha sempurna. ${ }^{52}$

184.

${ }^{48}$ Abi Al-Husain Ahmad bin Faris bin Zakaria, Al-Mu'jam Maqyis Al-Lugah Juz,I... hal.

${ }^{49}$ Ulama dalam arti universal, Yakni setiap Orang yang berilmu pengetahuan yang betul-betul ahli dibidangnya dan mengetahui kebesaran dan kekuasaan Allah Swt.

${ }^{50}$ Departemen RI. Al-Quran dan Terjemahnya... h.700.

${ }^{51}$ Muhammad bin Shalih, Sisilah A'mal al-Qulub,... hal.181.

${ }^{52}$ Muhammad bin Shalih, Sisilah A'mal al-Qulub,....hal.181. 


\section{Khauf Negatif}

Takut yang negative sebenarnya adalah bagian dari penyakit rohani atau jiwa. Ia dianggap sebagai salah satu perusak kepribadian seseorang, serta meruntuhkan dan menghambat kemajuan. Dalam istilah psikologis biasa disebut phobia atau cemas (takut yang berlegih-lebihan)..$^{53}$

Takut yang semacam ini banyak macam dan jumlahnya yang bisa dikatakan meliputi seluruh aspek kehidupan manusia. Misalnya, takut atau cemas menghadapi masa depan, tidurnya terganggu karena merasa dibayangi maling, tidak mau berdagang karena takut rugi, tidak mau berlayar karena takut tenggelam, dan sebagainya, yang kadang pula dengan alasan tidak tertentu.

Adnan Syarif, seorang pakar kejiwaan, membedakan ketakutan dan kecemasan dalam dua hal yaitu, penyakit ketakutan dan kecemasan dengan ketakutan dan kecemasan bersifat alamiah atau fsikologis. ${ }^{54}$ Hal yang terakhir ini merupakan perasaan kejiwaan berupa kesempitan yang dalam keadaan tertentu sering disertai dengan berbagai perubahan psikologis dalam menjalankan fungsi sebagian besar anggota tubuh. ${ }^{55}$

Adnan Syarif, menyebutkan beberapa jenis ketakutan alamiah yang bersifat negative, yang diambil dari Al-Qur'an, yang secara berturut-turut merupakan tingkat ketakutan dan kecemasan yang dialami oleh manusia, sebagai berikut:

1. Kesempitan jiwa. Q.S. al-Hijr (15): 97-99

2. Ketakutan. Q.S.al-Ahzab (33):19

3. Kegelisahan (kurang sabar). Q.S.al-Ma’arij (70): 20

4. Berkeluh-kesah (kurang sabar disertai dengan ketamakan yang luar biasa atas segala sesuatu). Q.S.al-Ma'arij (70): 19-22

5. Ketakutan yang berlebihan (lebih tinggi tingkatannya dari kegelisahan). Q.S.al-Anfal (8): 12

6. Kepanikan (lebih tinggi tingkatannya dari kegelisahan). Q.S.al-Anbiya (21): 103

${ }^{53}$ Hamzah Yałub, Tingkat Ketenangan dan Kebahagiaan Mukmin,..., hal. 128.

${ }^{54}$ Kedua hal ini, adalah penyakit ketakutan dan kecemasan serta ketakutan dan kecemasan alamiah sebenarnya adalah dua hal yang negative yang terdapat pada manusia. Namun terkadang ia dimaklumi sebagai sesuatu yang wajar yang sifatnya alami atau fitrawi yang dimiliki oleh manusia. Lihat Adnan Syarif, Min 'Ilm al-Nafs Al-Qur'ani, diterjemahkan oleh Muhammad al-Mighwar dengan Psikologi Qur'ani, Bandung: Pustaka Hidayah, 2002, hal. 86.

${ }^{55}$ Muhammad al-Mighwar dengan Psikologi Qur'an..., hal. 86. 
7. Kebingungan/linglung (gangguan ringan pada akal sebagai akibat dari ketakutan yang luar biasa) Q.S.al-Hajj (22): 1-2

8. Mabuk/setengah gila (hilang akal akibat ketakutan yang luar biasa). Q.S.al-Hajj (22): 2 .

Ketakutan yang dialami terhadap segala sesuatu yang tidak diketahui atau yang menakutkan ini acap kali mengancam diri manusia dan eksitensinya. Hal ini tidak hanya terbatas pada mereka yang awam saja, tetapi tidak jarang menimpa sebagian para nabi. Nabi Ibrahim, Musa, Dawud, dan Yunus misalnya, juga mengalami suatu ketakutan alamiah berbagai situasi yang dialaminya, sebagaimana disebutkan dalam sebagian kisah Al-Qur'an mulia. ${ }^{56}$. di antaranya yang disebutkan kisahnya dalam Al-Qur'an, yaitu kisah Nabi Ibrahim ketika didatangi oleh malaikat Q.S.al-Dzariat (51): 28:

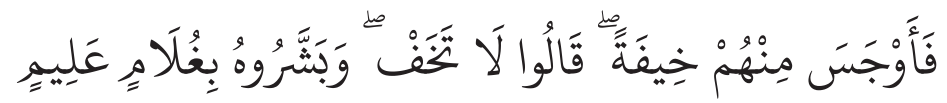

(Tetapi mereka tidak mau makan), Karena itu Ibrahim merasa takut terhadap mereka. Mereka berkata: "Janganlah kamu takut" dan mereka memberi kabar gembira kepadanya dengan (kelahiran) seorang anak yang $\operatorname{alim}$ (Ishak). ${ }^{57}$

Bagitu juga halnya dengan kisah nabi musa tatkala berada di built thursina Sebagaimana Firman Allah Swt. Pada QS. Al-Qashash (28): 31.

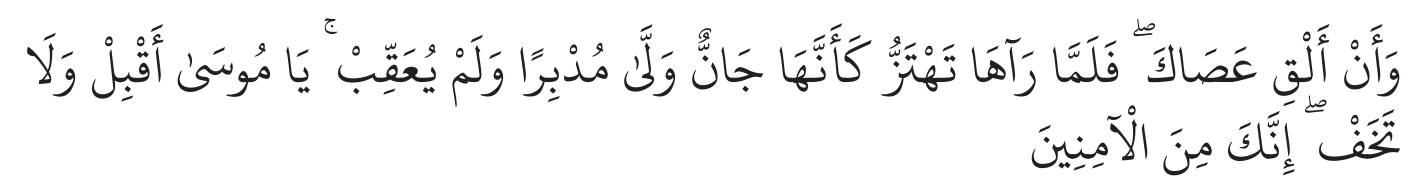

dan lemparkanlah tongkatmu. Maka tatkala (tongkat itu menjadi ular dan) Musa melihatnya bergerak-gerak seolah-olah Dia seekor ular yang gesit, larilah ia berbalik ke belakang tanpa menoleh. (Kemudian Musa diseru): "Hai Musa datanglah kepada-Ku dan janganlah kamu takut. sesungguhnya kamu Termasuk orang-orang yang aman. ${ }^{58}$

Namun ketakutan yang dialami oleh para Nabi di atas merupakan suatu hal yang wajar dimiliki oleh manusia biasa.

\footnotetext{
${ }^{56}$ Muhammad al-Mighwar dengan Psikologi Qur'ani,...hal. 86.

${ }^{57}$ Departemen Agama RI,, Al-Qur'an dan Terjemahnya...hal. 860.

${ }^{58}$ Departemen Agama RI Al-Qur'an dan Terjemahnya,..hal.614.
} 


\section{A. Pandangan Ulama Sufi Tentang Khauf}

Khauf merupakan suatu hal sangat urgen dalam kajian mistisime dalam Islam, bagi orang yang hendak menempuh jalan (suluk) kepada Tuhan. Jika hendak mengkaji khauf dalam berbagai literature mistisisme Islam, maka akan ditemukan bahwa ia termasuk kajian ahwal (keadaan-keadaan psikologi sufi). Hampir semua literatur tentang tasawuf yang membahas mengenai khauf, dibahas di dalam hal atau ahwal. Walaupun hampir semua jumhur sufi sepakat bahwa khauf berada tataran ahwal, namun ada beberapa ulama yang berbeda pendapat, seperti al-Qusyairi, memasukkan khauf ke dalam maqam. ${ }^{59}$

Pembahasan mengenai khauf dalam tasawuf tidak bisa dipisahkan dari pembahasan tentang raja' (harapan) ${ }^{60}$. Khauf dan Raja' bagaikan dua sisi koin yang tak terpisahkan. Dalam istilah al-Ghazali adalah "dua sayap, yang dengan kedua sayap itu orang-orang mendekatkan diri (muqarrabin) menuju tempat-tempat terpuji", atau "ia (khauf dan raja) adalah dua pedang, dengan ke dua pedang itu orang yang berjalan menuju akhirat (salik) memutus semua tebing yang sukar didaki. ${ }^{61}$

Menurut al-Qusyairi, takut kepada Allah berarti takut kepada hukum-Nya, seperti firman-Nya Q.S. Ali-Imran (3): 175:

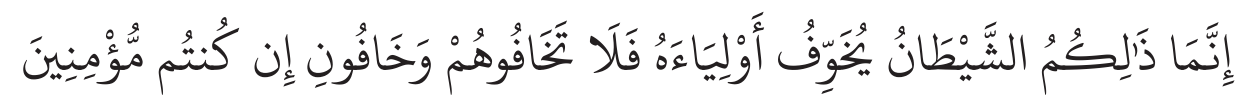

Sesungguhnya mereka itu tidak lain hanyalah syaitan yang menakut-nakuti (kamu) dengan kawan-kawannya (orang-orang musyrik Quraisy), karena itu janganlah kamu takut kepada mereka, tetapi takutlah kepada$\mathrm{Ku}$, jika kamu benar-benar orang yang beriman. ${ }^{62}$

\footnotetext{
${ }^{59}$ Merujuk ke catatan kaki no.9. Pembahasan mengenai maqam dan ahwal adalah pembahasan yang menjadi perhatian sangat menarik dalam tasawuf, yang manakah lebih dahulu atau lebih mulia. Para ulama membedakannya dari segi sampainya, sehingga mereka terkadang mendahulukan yang satu dari pada yang lain. Namun secara singkat dapat disebutkan, sebagaimana pernyataan beberapa ulama sufi, di antaranya, seperti perkataan al-Qusyairi,"Setiap hal adalah merupakan karunia (mahawib) dan setiap maqam adalah usaha (makasib)." Lihat al-Qusyairi, Risalah al-Qusyairi,... h. 206. Pendapat tersebut merupakan kesepakatan para ulama sufi yang lain, seperti al-Sarraj, al-Junaid, al-Hujwiri, dan lain-lain. Bandingkan dengan Annimarie Schimel, Dimensi mistik dalam Islam, h. 102. Media Zainul Bahri, Menembus Tirai Kesendirian-Nya..., hal. 31-45. al-Hujwiri, Kasyful Mahjub,..., hal. 170-178.

${ }^{60}$ Raja' adalah suatu sikap mental optimisme dalam memperoleh karunia dan nikmat Ilam hi yang disediakan bagi hamba-hamba-Nya yang shaleh. Lihat Rivai Siregar, Tasawuf dari Sufusme Klasik ke Neo-Sufisme,.. hal. 134.

${ }^{61}$ Al-Ghzali, Masalah Tajut dan Harap, diterjemahkan oleh M. Abdul Majieb AS., Surabaya: Mahkota, t.th, hal. 8 .

${ }^{62}$ Departemen Agama RI, Al-Qur'an dan Terjemahnya,...hal. 106.
} 
Khauf atau takut, lanjut al-Qusyairi, adalah masalah yang berkaitan dengan kejadian yang akan datang, sebab seseorang hanya merasa takut jika apa yang dibenci tiba dan yang dicintai sirna. Dan kenyataan itu hanya terjadi di masa yang akan datang. ${ }^{63}$

Senada dengan al-Qusyairi, al-Gazali juga memandang khauf sebagai hati yang sakit dan terbakar karena adanya bayangan atau imajinasi tentang adanya yang dibenci akan menimpa diri di masa yang akan datang. ${ }^{64}$ Sementara Abu Hafs menerangkan bahwa takut (khauf) adalah cambuk Allah yang digunakan-Nya untuk menghukum manusia yang berontak keluar dari ambang pintunya. Takut, menurutnya, adalah pelita hati, dengannya akan tampak baik dan buruknya hati seseorang. ${ }^{65}$

Sementara ibn Qayyim al-Jauziyah memandang khauf sebagai perasaan bersalah dalam setiap tarikan nafas. Perasaan bersalah inilah yang menyebabkan orang lari menuju Allah. Menurutnya, untuk memunculkan rasa bersalah seseorang harus mengingat dosa-dosa yang pernah dilakukannya sambil merasa khawatir kalau-kalau masih tergodaoleh setan dalam setiap tarikan nafas, dan khawatir kalau-kalau Allah tidak menerima kehadirannya. ${ }^{66}$

Dalam Pandangan al-Sarraj khauf senantiasa bergandengan dengan mahabbah (cinta), kaduanya tidak dapat dipisahkan dan masih dalam bingkai qurb (kedekatan). ${ }^{67}$ Oleh karenanya Qurb itu membutuhkan dua kondisi. Perta$m a$, dalam hati sang hamba yang dominan adalah rasa takutnya karena ia memandang kedekatan Allah padanya maka qurb-nya itu berbentuk khauf. Kadua dalam hati sang hamba yang dominan adalah rasa cintanya (Mahabbah) maka Qurb itu berbentuk mahabbah. ${ }^{68}$

Selanjutnya al-Sarraj membagi khauf kedalam tiga tingkatan. Pertama Khauf-nya orang-orang awam. Mereka takut kepada Allah semata karena takut murka dan siksa-Nya. Kondisi mereka sesuai dengan firman Allah pada Q.S.alNur (24): 27

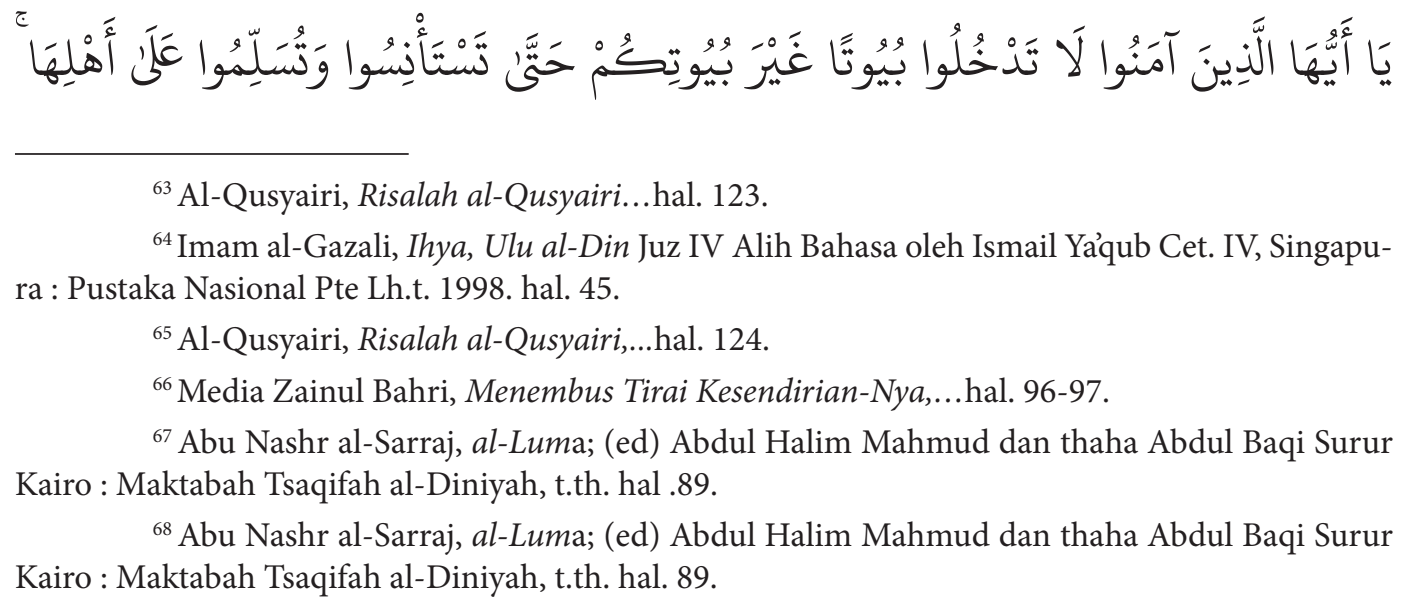
ra : Pustaka Nasional Pte Lh.t. 1998. hal. 45.

${ }^{65}$ Al-Qusyairi, Risalah al-Qusyairi,...hal. 124.

${ }^{66}$ Media Zainul Bahri, Menembus Tirai Kesendirian-Nya,...hal. 96-97.

${ }^{67}$ Abu Nashr al-Sarraj, al-Luma; (ed) Abdul Halim Mahmud dan thaha Abdul Baqi Surur Kairo : Maktabah Tsaqifah al-Diniyah, t.th. hal .89.

${ }^{68}$ Abu Nashr al-Sarraj, al-Luma; (ed) Abdul Halim Mahmud dan thaha Abdul Baqi Surur Kairo : Maktabah Tsaqifah al-Diniyah, t.th. hal. 89. 


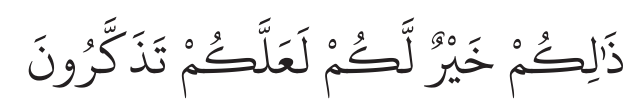

laki-laki yang tidak dilalaikan oleh perniagaan dan tidak (pula) oleh jual beli dari mengingati Allah, dan (dari) mendirikan shalat, dan (dari) membayarkan zakat. mereka takut kepada suatu hari yang (di hari itu) hati dan penglihatan menjadi goncang. ${ }^{69}$

Kedua, Takutnya orang-orang (awsath). Mereka takut diputuskan dari beningnya ma'rfat kepada Allah Swt. Mereka takut jika Allah memutuskan mereka dari manisnya mengetahui dan mengenal Allah (ma'rifah). Kondisi mereka beredasarkan firman Allah Swt. Pada Q.S. al-Rahman (55): 46.

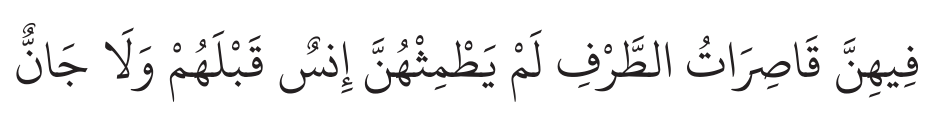

Dan bagi orang yang takut akan saat menghadap Tuhannya ada dua syurga. ${ }^{70}$

Yang dimaksud dua syurga di sini adalah, yang satu untuk manusia yang satu lagi untuk jin. ada juga ahli tafsir yang berpendapat syurga dunia dan syurga akhirat. ${ }^{71}$

Ketiga, Takutnya orang-orang khusus (khawas). Rasa takut mereka bisa juga disebut rasa takut meskipun hal yang masih jauh terjadi (khauf al-ajillah). ${ }^{72}$ Kondisi mereka didasarkan pada firman Allah Swt. Pada Q.S. Ali Imran(3): 175.

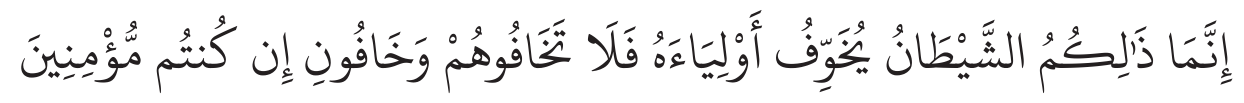

Sesungguhnya mereka itu tidak lain hanyalah syaitan yang menakut-nakuti (kamu) dengan kawan-kawannya (orang-orang musyrik Quraisy), karena itu janganlah kamu takut kepada mereka, tetapi takutlah kepada$\mathrm{Ku}$, jika kamu benar-benar orang yang beriman. ${ }^{73}$

Hasan Al-Basri terkenal sebagai tokoh yang pertama memperkenalkan konsep khauf dalam tasawuf selain zuhud (zuhud). Metode muraqabah-nya adalah zuhud, tawakkal dan khauf. Dia pernah didatangi seorang Badui dam Badui

${ }^{69}$ Departemen Agama RI, Al-Qur'an dan Terjemahnya,...hal. 550.

${ }^{70}$ Departemen Agama RI, Al-Qur'an dan Terjemahnya,...hal. 888.

${ }^{71}$ Departemen Agama RI, Al-Qur'an dan Terjemahnya,...h.888.

${ }^{72}$ Abu Nashr al-Sarraj, al-Luma; (ed) Abdul Halim Mahmud dan thaha Abdul Baqi Surur ... h.90.

${ }^{73}$ Departemen Agama RI, Al-Quran dan Terjemahnya,... h. 106. 
itu berkata "Engkau adalah seorang zuhud, aku tak pernah melihat seseorang yang lebih zuhud darimu." Wahai Badui seru Hasan al-Basri kezuhudanku tak

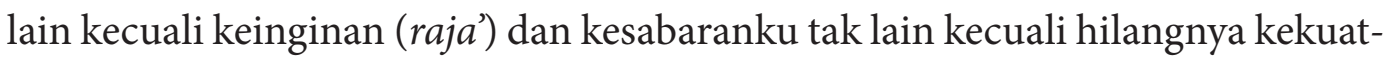
an. Orang badui itu meminta supaya dia menerangkan ujaran ini. Hasan al-Basri menjawab : "Kesabaranku dalam kemalangan dan kepasrahanku menyatakan rasa takutku akan api neraka dan inilah hilangnya kekuatan (jaza'), dan kezuhudan didunia ini adalah mendambakan akhirat, dan inilah hakikat keinginan $(\text { raja, })^{74}$

Ibn 'Atha'illah menyatakan bahwa hanya "ketakutan yang menggetarkan" (khauf muz'ij) atau "rindu yang menggelisahkan" (syauq muqliq) yang dapat mengusir syahwat dalam hati. Ketakutan yang menggetarkan (khauf muz'ij) berkaitan dengan ketakutan dan kebesaran Tuhan (al-Jalal). Rindu yang menggelisahkan (syauq muqliq) berkaitan dengan keindahan Tuhan (al-Jamal) yang membuat daya tarik sehingga melahirkan nafsu yang mengikat sang murid dan menunjukkan kepada yang di atas. ${ }^{75}$

Sependapat dengan al-Gazali, Annimarie Schimmel, juga menjelaskan tentang ketakutan para sufi dari maker Tuhan, bukan lagi ketakutan terhadap pengadilan Tuhan atau kengerian neraka. Para sufi tidak pernah pasti yakin apakah Tuhan tidak memanfaatkan keadaan yang mulia ini (tingkat spiritual) sebagai perangkap untuk menjebaknya, merayunya lagi dengan pikiran keduniaan, kebanggaan, dan kemunafikan, agar ia terkecoh dari tujuan yang tertinggi. Mukjizat misalnya, masih ada hubungannya dengan dunia, bahkan dalam kesenangan-kesenangan kecil sehari-hari, boleh jadi tersembunyi tipu daya Allah yang patut ditakuti. ${ }^{76}$

Adapun khaufyang selain Allah tidak berkaitan dengan Dzat-Nya terbagi menjadi dua bagian:

Pertama, khauf atas sirnahnya nikmat. Ketakutan ini mendorong hamba pada adab yang santun dan menunggu-nunggu anugerah (al-mannah). Kedua, khauf terhadap sanksi-sanksi berupa siksaan yang dijatuhkan atas pelanggaran yang dilakuakn (al-Jinayat). Batasan definisi khauf yang kedua ini adalah khauf yang menjadi pendorong untuk meninggalkan hal-hal yang dilarang (al-mah$d z u r a t$ ) dan menerapkan perintah-perintah yang wajib (wajibat). ${ }^{77}$

${ }^{74}$ Al-Hujwiri, Kasyful Mahjub... h. 88-89.

${ }^{75}$ Victor Danner, Ibn 'Atha'illah's Shufi Aporisisme (Kitab al-Hikam), diterjemahkan oleh Rouslan dengan judul, Mistilisme Ibn 'Atha'illah; Wacana Sufistik (Kajian Kitab al-Hikam), Surabaya: Risalah Gusti, 1999, hal. 93.

${ }^{76}$ Annimarie Sc Opbhimel, Dimensi Mistik dalam Islam,... hal. 132.

${ }^{77}$ Annimarie Sc Opbhimel, Dimensi Mistik dalam Islam,...hal. 201-202. 


\section{B. Pemahaman M. Quraish Shihab Tentang Ayat-Ayat Khauf}

Kecenderungan bertasawuf muncul seiring dengan kesadaran seorang akan hakikat keberadaan dirinya dipentas dunia. Secara naluriah, menurut Adnan Syarif, setidaknya setiap orang yang berakal biasanya pernah bertanya-tanya diantara dirinya dan jiwanya tentang eksetensinya, fungsi dan tujuannya, serta akhir dari eksetensinya. ${ }^{78}$ Oleh karena itu, setiap manusia selalu berusaha untuk mengetahui jawabannya dari ketiga pertanyaan di atas dengan melakukan berbagaic cara. Salah satunya adalah dengan bertasawuf.

Tasawuf merupakan sebuah tradisi spiritual yang paling luas dikenal dalam sejarah agama-agama. Berpijak dari sumber utamanya, yakni Al-Quran dan Haits. Kecenderungan mistik ini, telah memainkan peran yang penting dalam sejarah keyakinan umat Islam, baik dalam perkembangan kualitas pribadi maupun kolektif. ${ }^{79}$ Tasawuf juga adalah berbagai bentuk kehidupan yang menjauhi kemewahan, menghabiskan waktu untuk beribadah, rindu untuk berjumpa dengan Tuhan, dan siap setiap saat untuk dipanggil menghadap Allah. ${ }^{80}$

Selanjutnya, dikenal tiga macam ajaran tasawuf yaitu: 1) tasawuf amali yaitu ajaran tasawuf yang mengedepankan penanaman akhlak semata. 2) tasawuf nazari yaitu ajaran tasawuf yang memperkenalkan konsep-konsep dan teminologi baru dalam tasawuf biasanya juga disebut dengan tasawuf teoritis. 3) tasawuf falsafi yaitu perpaduan antara pencapaian pencerahan mistikal dan pemaparan secara rasional-filosofis. ${ }^{81}$

M. Quraish Shihab, sebagai pakar Tafsir dan Ulumul Quran, bukanlah pakar tasawuf sebagaimana pakar tasawuf lainnya. Ia tidak mempunyai teori-teori yang dapat disimpulkan bahwa ia termasuk dalam kategori sufi. Namun dari beberapa pendapatnya dapat dilihat aspek-aspek tasawuf yang mempengaruhi dan dia dapat dikategorikan sebagai pengamal tasawuf amali/akhlaqi.

Dalam pengakuannya ${ }^{82}$ pemikiran tasawufnya banyak dipengaruhi oleh dua orang tokoh yaitu, al-Habib Abdul bin Ahmad Bilfaqih, yang menjadi guru sekaligus mursyid beliau, dan Syeikh Abdul Halim Mahmud, pimpinan tertinggi ai Al-Azhar. ${ }^{83}$

\footnotetext{
${ }^{78}$ Adnan Syarif, Psikologi Qurani,...hal. 84.

${ }^{79}$ Michael A. Sells, Sufisme Klasik,... hal. 1.

${ }^{80}$ Kata Sambutan dalam A. Rivay Siregar, Tasawuf; Dari Sufisme Klasik ke Neo-Sufisme,...

${ }^{81}$ A. Rivay Siregar, Tasawuf; Dari Sufisme Klasik ke Neo-Sufisme,... hal. 32.

${ }^{82}$ M. Quraish Shihab, Logika Agama,... hal. 19.

${ }^{83}$ M. Quraish Shihab, Logika Agama,... hal. 20-23.
} hal. 32 . 
Dari tokoh pertama ia memperoleh pengajaran tentang zuhud yang mengajarkannya mengenai kesederhanaan hidup, wara' tawadhu dan keikhlasan ia mengakui bahw ahubungan spiritual dengan guru pertamanya ini masih terjalin hingga sekarang walaupun gurunya tersebut telah meninggal dunia. ${ }^{84}$

Dari tokoh kedua, ia memperoleh pengajaran salain kezuhudan juaga peranan akal dan agama. Sebab gurunya tersebut "pengagum al-Gazalipada abad ke XIVH.” Dalam buku logika agama dijelaskan dengan penjang bagaimana tersebut membentuk kepribadiannya ${ }^{85}$

Selain itu, pendapat M. Quraish Shihab tentang ihsan, dapat dijadkan acuan untuk melihat pemahaman sufistiknya, Ihsan menurutnya adalah member lebih banyak dari pada yang anda dapat dan mengambil sedikit daripada yang seharusnya anda ambil. ${ }^{86}$ Ihsan itu, masih menurutnya, tercapai dalam dua hal, pertama, ihsan terhadap amba, yaitu jika seseorang memandang dirinya pada diri orang lain sehingga ia member untuknya apa yang seharusnya dia beri untuk dirinya. Dalam arti, dia tidak lagi melihat dirinya akan tetapi dia hanya melihat orang lain. Kedua, ihsan terhadap Allah Swt. Yaitu leburnya diri sehingga dia hanya 'melihat' Allah Swt. Dalam arti hamba tidak lagi melihat dirinya kecuali hanya melihat kepada Allah Swt. ${ }^{87}$

M. Quraish Shihab memahami bahwa khauf merupakan salah satu factor utama dari lahirnya amal-amal saleh dan menghindari diri dari keburukan, dan menghindar keburukan (takhalli) lebih diutamakan dari pada menghiasi diri dari kebaikan (tahili). ${ }^{88}$ Dalam Tafsir al-Misbah, ditemukan pemahaman sufistinya terhadap ayat-ayat yang dibicarakan tentang khauf. Seperti Q.S. Al-Naziat (79): 40 .

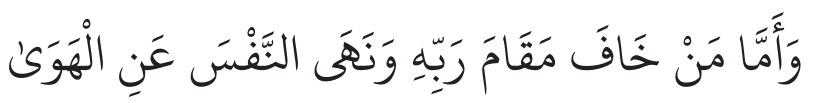

Dan adapun orang-orang yang takut kepada kebesaran Tuhannya dan menahan diri dari keinginan hawa nafsnya. ${ }^{89}$

Kata مَقَّـاحَ رَبَّــــ pada ayat di atas, dipahami oleh M. Quraish Shihab dengan dua pemáhaman. Pertama dapat dipahami sebagai kedudukan Allah di hari kiamat, sehingga khauf dalam ayat ini dipahami sebagai takut menghadapi

\footnotetext{
${ }^{84}$ M. Quraish Shihab, Logika Agama,... hal. 24.

${ }^{85}$ M. Quraish Shihab, Logika Agama,....hal. 25.

${ }^{86}$ M. Quraish Shihab, Logika Agama,...hal. 16.

${ }^{87}$ M. Quraish Shihab, Logika Agama,...hal. $16 .$.

${ }^{88}$ M. Quraish Shihab Tafsir Al-Misbah, vol. 14, hal. 494.

${ }^{89}$ Departemen Agama RI, Al-Quran dan Terjemahnya ,...hal. 869.
} 
perhitungan-Nya. Kedua, dapat dipahami bahwa berkaitan dengan Zat Allah, maka khauf dalam ayat ini berarti keagungan Allah SWT. Sehingga takut yang dimaksud adalah kedudukan kepada Allah, karena Dia adalah yang wajar dicintai selaku rabb, yakni Tuhan yang membimbing, memelihara, dan menganugerahkan aneka rahmat serta yang menyandang sifat-sifat Yang Maha Terpuji..$^{90}$ Selain itu, hal semakna juga ditampilkan ketika menafsirkan ayat Q.S. Al-Rahman: $46 .{ }^{91}$ Demikian juga pengertian ini digunakan ketika menafsirkan tentang takutnya para malaikat dalam Q.S. An-Nahl: 50. ${ }^{92}$ Para malaikat merasa takut karena menyaksikan maqam Ilahi yang demikian tinggi itulah sebab ketakutan mereka.

Selanjutnya, dalam Q.S. Yunus (10): 15.

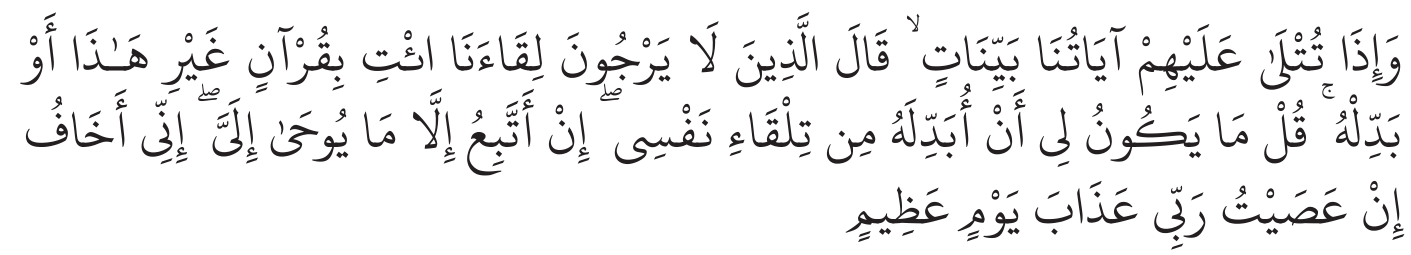

Dan apabila dibacakan kepada mereka ayat-ayat Kami yang nyata, orang-orang yang tidak mengharapkan Pertemuan dengan Kami berkata: "Datangkanlah Al Quran yang lain dari ini atau gantilah dia". Katakanlah: "Tidaklah patut bagiku menggantinya dari pihak diriku sendiri. aku tidak mengikut kecuali apa yang diwahyukan kepadaku. Sesungguhnya aku takut jika mendurhakai Tuhanku kepada siksa hari yang besar (kiamat)". ${ }^{93}$

M. Quraish menafsirkan bahwa rasa takut dalam ayat di atas adalah rasa takut yang dimiliki oleh Rasulullah yang ditujukan kepada 'În1u', yaitu Allah. Sifat Rabubiyah inilah yang menjadikan Rasulullah SAW takut. Di dalam Al-Quran hampir seluruh ayat tentang khauf yang dikaitkan kepada Allah selalu menggunakan kata 'În $1 u^{\prime}$, ini berarti Al-Quran menganjurkan bahwa takut kepada Allah itu hendaknya karena berupa kekaguman akan keagungan dan kebesaran-Nya.

Dari penjelasan di atas dapat dipertegas mengenai pemahaman M. Quraish Shihab terhadap khauf, sebagai berikut:

1. Khauf sebagai motivator penting lahirnya amal salah dan menghindarkan diri dari pergbuatan buruk. (Q.S. al-Naziat (79):40, Q.S Al-Rahman (55): 46, Q.S. Al-Nahl (16): 50.

\footnotetext{
${ }^{90}$ M. Quraish Shihab Tafsir Al-Misbah, vol. 14,... hal. 48-49.

${ }^{91}$ M. Quraish Shihab Tafsir Al-Misbah, vol. 13,... hal. 526-527.

${ }_{92}$ M. Quraish Shihab Tafsir Al-Misbah,... vol. 7 , hal. 246-247.

${ }^{93}$ Departemen Agama RI, Al-Quran Dan Terjemahnya,... hal. 307-308.
} 
2. Khauf sebagai berarti ketundukan kepada Rabb (Allah Swt) (Q.S. Yunus (10): 15.

3. Khauf dalam arti keresahan hati terhadap hal-hal yang buruk, seperti kelaparan dan sebagainya, sehingga ia bermakna umum (Q.S. al-Baqarah (2): 155.

4. Khauf dalam arti ketakutan biasa yang dialami oleh pribadi, sehingga ia bermakna khusus. (Q.S. Thaha (20): 67-68)

5. Khauf dalam kehidupan berada pada wilayah "mungkin" dalam arti bisa terjadi bias tidak, karena ia merupakan ketakutan terhadap sesuatu yang akan datang.

6. Khauf dalam ibadah berarti penyempurnaan pengabdiaan kepada Allah Swt..

Dari pemahaman ini, M. Quraish Shihab hendak mengungkapkan bahwa ketakutan kepada Allah adalah sesuatu yang dimiliki oleh semua hamba baik yang kelasnya lebih tinggi (high class) atau telah berada dekat dengan Allah, maupun yang masih memulai menempuh jalan kepada Tuhan.

Dari sini, M. Quraish Shihab hendak menyederhanakan pengertian khauf yang berada dengan apa yang di pahamai oleh para sufi. Jika para sufi terkesan memahami khauf dalam pengertian yang "melangit", M. Quraish Shihab malah hendak "membumikan" pemahaman khauf itu sendiri. Hal ini tidak terlepas dari background beliau sebagai orang yang bergelut dalam bidang tafsir sehingga maksud khauf mudah dipahami dan dipraktekkan dalam kehidupan beragama..$^{94}$

\section{A. Implikasi Khauf}

Takut merupakan suatiu kondisi jiwa yang sifatnya alami dan ia termasuk sesuatu yang bersifat naluriyah. Hampir semua tingkah laku dan perbuatan manusia berlandaskan rasa takut. Tidak mengherankan, jika manusia selalu mencari dan bahkan menciptakan sesuatu, baik yang sifatnya materi atau non materi, untuk melindunginya dari ketidak-nyamanan, ketakutan, kegelisahan dan atau kecemasan. Rasa takut bagi manusia selalu ada dalam setiap kehidupannya, sebab hal itu sudah dijanjikan oleh Allah dalam Al-Quran Q.S. Al-Baqarah (2): 155:

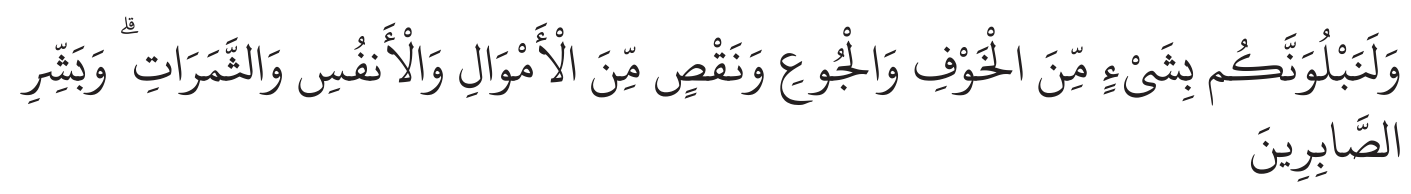

${ }^{94}$ M. Quraish Shihab Tafsir Al-Misbah,....... vol. 7, hal. 246-247. 
Dan sungguh akan Kami berikan cobaan kepadamu, dengan sedikit ketakutan, kelaparan, kekurangan harta, jiwa dan buah-buahan. dan berikanlah berita gembira kepada orang-orang yang sabar. ${ }^{95}$

Ayat di atas menjelaskan tentang cobaan yang akan dihadapi oleh selama manusia berada di dunia. Salah satunya adalah rasa takut. Kalimat الخَْوْفِ rut M. Quraish Shihab yakni mengandung makna, keresahan hati menyangkut sesuatu yang buruk, atau hal-hal yang tidak menyenangkan yang diduga akan terjadi. ${ }^{96}$ Dalam ilmu kejiwaan (psikologi) rasa takut dianggap sebagai sesuatu penyakit jiwa, apabila rasa takut itu berlebihan yang disebut phobia atau cemas yang berlebihan. ${ }^{97}$

Pada pembahasan sebelumnya, telah dijelaskan tentang khauf positif dan khauf negative. Kedua khauf ini selalu muncul dalam diri manusia tergantung kondisi yang dialaminya. Seperti kisah Nabi Musa yang bnyak dikisahkan dalam Al-Quran, salah satu contohnya misalnya Q.S. Thaaha (20): 67-68:

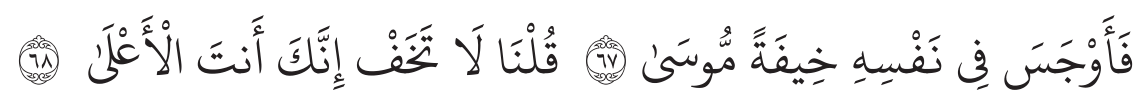

Maka Musa merasa takut dalam hatinya. Kami berkata: "Janganlah kamu takut, Sesungguhnya kamulah yang paling unggul (menang). "98

Ayat di atas jelas menggambarkan rasa takut yang dialami Nabi Musa. Para ulama berbeda pendapat tentang sebba ketakutan Nabi Musa tersebut. Ada yang berpendapat bahwa beliau khawatir jangan sampai orang-orang yang melihat keberhasilan penyihir-penyihir itu sehingga tidak dapat membedakan antara sihir dengan mukjizat. Ada juga yang berpendapat bahwa ketakutan tersebut boleh jadi disebabkan oleh kekhawatiran ditinggalkan oleh penonton setelah puas dengan suguhan para penyihir, atau beliau khawatir jangan sampai Allah mengulur waktu bagi penyihir dan Fir'aun sehingga ketika itu mereka yang dimenangkan-Nya untuk sementara. ${ }^{99}$

Menurut M. Quraish Shihab, pendapat di atas sedikit dipaksakan. Menurutnya terlintasnya rasa takut dalam situasi seperti yang semacam itu merupakan sesuatu manusiawi. Perasaan Nabi Musa itu sama sekali bukanlah rasa takut yang menonjol, tidak juga menguasai jiwa dalam waktu yang lama. Sebab

\footnotetext{
${ }^{95}$ Departemen Agama RI, Al-Qur'an Dan Terjemahnya... hal. 39.

${ }^{96}$ M. Quraish Shihab, Tafsir Al-Misbah vol. 1,... hal. 342

${ }^{97}$ Hamzah Ya’qub, Tingkat Ketenangan dan Kebahagiaan Mukmin,... hal. 128-129.

${ }^{98}$ Departeman Agama RI, Al-Qur'an Dan Terjemahnya,... hal. 483.

${ }^{99}$ M. Quraish Shihab Tafsir Al-Misbah,...., vio. 8, hal. 328-329
} 
Allah sebelumnya telah menjanjikan kepada Nabi Musa bahwa ia akan selalu akan bersama Musa dan Harun. Kata تَ تَنْ mengisyaratkan ketakutan itu hanya terlintas dalam dirinya, dan tidak nampak pada gerak-gerik atau air mukanya. ${ }^{100}$

Dari contoh di atas, jelaslah bahwa ketakutan para Nabi bukanlah ketakutan yang sifatnya negative atau khauf negative. Sebab ketakutan yang dialami oleh para tersebut merupakan ketkuatan biasa, dan itu menjadi indikasi bahwa sesungguhnya para Nabi adalah manusia biasa.

Rasa takut menyangkut sesuatu yang bakal terjadi dimasa yang akan datang, bisa jadi sangat besar dan berbahaya, dan bisa jadi kecil dan remeh, juga hal tersebut merupakan keniscayaan, bias juga berpotensi untuk terjadi atau tidak terjadi. Karena itu, menurut Quraish Shihab, rasa takut itu berada pada wilayah "mungkin". ${ }^{101}$

Maka dari itu, sebab munculnya bermacam-macam. Ia bias berasal dari diri yang bersangkutan sendiri atau dan boleh jadi dari pihak lain. ${ }^{102}$ Menurut Al-Ghazali, sebab dominant muncul rasa takut itu adalah pengetahuan atau il$\mathrm{mu},{ }^{103}$ mengenai sesuatu hal yang berdampak pada kemaslahatan maupun kemudharatan. Semakin luas pengetahuan atau ilmu yang dimiliki, maka semakin besar pula rasa takut itu muncul, dan demikan pula sebaliknya.

Khauf merupakan keadaan dimana jiwa berada pada keadaan takut, maka dampaknya akan terlihat pada fisik seperti pucat atau tubuh gemetar, atau pada tingkah laku dan perbuatan.

Khauf bagi para penempuh perjalanan spiritual bukanlah tujuan utama dalam arti tujuan yang sebenarnya, bukan untuk membuat agar takut semata-mata, melainkan harus menjadikan rasa takut sebagai sarana untuk memperbaiki keadaan mereka. Seandainya rasa takut adalah tujuan yang menajdi sasaran, tentulah rasa takut tidak akan pernah hilang dari penduduk surga. Padahal Allah telah berfirman Q.S. Yunus (10):62:

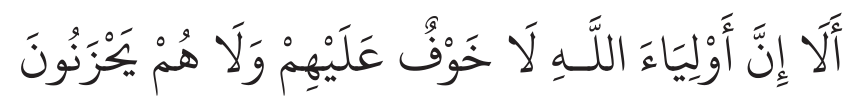

Ingatlah, Sesungguhnya wali-wali Allah itu, tidak ada kekhawatiran terhadap mereka dan tidak (pula) mereka bersedih hati. ${ }^{104}$

\footnotetext{
${ }^{100}$ M. Quraish Shihab Tafsir Al-Misbah,...., vio. 8, hal. 328-329.

${ }^{101}$ M. Quraish Shihab Menjemput Maut;Bekal Perjalanan Menuju Allah SWT, (Jakarta: Lentera Hati, 2002), hal. 42.

${ }^{102}$ M. Quraish Shihab, Menjemput Maut;Bekal Perjalanan Menuju Allah SWT,... hal. 42.

${ }^{103}$ Al-Ghazali, Takut dan Harap,...hal. 8.

${ }^{104}$ Departemen Agama RI, Al-Quran dan Terjemahnya,...h. 316.
} 
Prinsip mereka adalah barang siapa yang merasa takut pada hari ini (dalam kehidupan dunia), niscaya akan merasa aman pada hari esoknya (hari kiamat nanti): dan barang siapa yang merasa aman pada hari ini, niscaya akan merasa takut pada hari esok. ${ }^{105}$ Yakni merasa takut dari ancaman-ancaman Allah dalam berbuat dosa. ${ }^{106}$ Oleh karena itu, dalam kehidupan, takut disamping merupakan penyakit jiwa, juga merupakan satu hal yang sangat penting dalam membina akhlak manusia.

\section{PENUTUP}

\section{A. Kesimpulan}

Dari berbagai uraian di atas, setidaknya dapat memberikan gambaran tentang khauf. Oleh karena itu, gambaran tersebut dapat dirumuskan ke dalam beberapa poin sebagai kesimpulan pembahasan sebelumnya, sebagai berikut:

1. M. Quraish Shihab lahir di Rappang, Sulawesi Selatan pada Tgl 16 Februari 1944. Ibunya bernama Asma Aburisyi dan ayahnya bernama Abdurahman Shihab (1905-1986) seorang guru besar dalam bidang tafsir yang juga mantan Rektor IAIN Alauddin Makassar Pada Tahun1972-1977) (UIN Makassar Sekarang). M. Quraish Shihab Mempunyai lima orang anak dari istrinya tercinta, Fatmawati Assegaf yaitu: Najela Shihab, Najwa Shihab, Nashwa Shihab, Ahmad Shihab, dan Nahla Shihab. M. Quraish Shihab banyak mengahasilkan karya-karya monumental di antaranya Tafsir Al-misbah.

2. Inti dari pokok pikiran Tasawuf M. Quraish Shihab tentang khauf adalah memberikan pemahaman bahwa sesungguhnya Allah adalah Rabb al-'Alamin yang berarti Allah adalah Pemelihara, Pembimbing. Dari sini beliau memahami bahwa inti takut sesungguhnya adalah takut karena melihat dan mengetahui betul akan kebesaran dan kemuliaan yang dimiliki oleh Rabb al-Alamin, sehingga takut untuk melanggar perintah-Nya dan takut untuk melaksanakan larangan-Nya serta takut tidak melihat maqam-Nya. Di dalam Al-Quran, hampir semua ayat yang berbicara tentang khauf kepada Allah selalu menggandeng kata Rabb itu membuktikan bahwa takut sesungguhnya hanya kepada Allah Swt.

3. Pemahaman M. Quraish Shihab bahwa Khauf pada intinya adalah sebuah keadaan jiwa dimana seseorang merasa gentar disebabkan ada sesuatu yang tidak dikehendaki atau yang tidak disenangi yang akan menimpa dirinya di masa yang akan datang, baik itu karena kelalaian maupun karena kesada-

\footnotetext{
${ }^{105}$ Muhammad bin Shalih Al-Munajjid, Silsilah A'mal al-Qulub,... h. 186.

${ }^{106}$ Muhammad bin Shalih Al-Munajjid, Silsilah A'mal al-Qulub,... h. 197-211.
} 
ran. Di dalam khauf terdapat dua hal, yakni khauf positif dan khauf negatif. Khauf positif akan menguasai seseorang dan mengantarnya pada hal-hal positif, jika berada pada posisi yang benar. Begitu juga sebaliknya khauf itu akan negative dan berimbas kepada yang tidak baik, jika berada pada posisi yang salah.

\section{B. Implikasi}

1. Pemahaman terhadap khauf yang benar akan mengantarkan seseorang pada perilaku terpuji, terutama pada hal kedekatan (qurb) kepada Tuhan. Karena dalam qurb terhadap hub (cinta) yang dapat menjadikan seseorang mengenal (ma'rifah) kepada Tuhan semesta alam.

2. Melihat bahwa begitu banyak ayat yang berbicara mengenai khauf dalam Al-Quran, maka ini berarti diperlukan penelitian yang lebih mendalam dan lebih komperenshif lagi, tidak hanya sebatas kajian Tasawuf belaka dan pandangan satu tokoh saja.

\section{DAFTAR PUSTAKA}

Anshari, Zafar Afar. Quranic Concepts of Human Psich, Diterjemahkan oleh Abdullah Ali, Al-Quran Bicara Tentang Jiwa, Jakarta : Arasy, 2003.

Al-Asfahani, Al-Raghib. Al-Mufradat fi Gharib al-Quran, Kairoa: Dar al-Ma'rifah 2004.

AS, Asmaran. Pengantar Studi Tasawwuf Jakarta:Raja Grafindo persada, 2002.

Bahri,Media zainul. menembus tirai kesendirian-Nya Mengurai maqamat dan Ahwal dalam Tradisi sufi, Jakarta Pranada2005.

Bakhtiar, Lelah. Moral Healing Trough The Most Beatiful Names; The Practice of Spiritual Cviliry. Alih Bahas oleh Fammy Syahrani, Dengan Meneladani Akhlak Allah Melalui Asma' al-Husna Metode sufi Untuk Mengasah SQ dan EQ Bandung: Mizan, 2002.

Danner, Victor Ibn 'Atha'illah's Shufi Aporisisme (Kitab al-Hikam), Mistilisme Ibn 'Atha'illah; Wacana Sufistik (Kajian Kitab al-Hikam), Surabaya: Risalah Gusti, 1999.

Departemen Agama RI. Al-Quran dan terjmahnya, Jakarta : Kathoda, 2005.

Al-Gazali, Imam. Ihya' Ulum al-Din Juz IV Alih Bahasa oleh Ismail Ya'qub Cet. IV, Singapura : Pustaka Nasional Pte Lh.t. 1998.

-------. Masalah Takut dan harapan Surabaya: Mahkota, 1986

Gusmian, Islah. Kazanah Tafsir Indonesia: dari hermenetika hinggaI deologi Bandung: Teraju, 2003. 
El-Haridi, As'ad. Aliran-Aliran Kepercayaan Dan Kebatinan Di Indonesia, Jakarta: Ghalia Indonesia, 1997.

Ilyas, Yanahar. Kuliah Akhlak, (Yogyakarta: Lembaga Pengkajian dan pengamalan Islam LPPI, t.th.

Izutsu, Tashiko. Etico Religius Consepts in The Quran, Alih Bahasa oleh Fahri Huein at. al., dengan judul: Konsep Etika Religius dalam Al-Qur'an, Yogyakarta: Tiara Wacana Yogya, 1993.

Mahjub, Al-Hujrawi. Kasyful Risalah tertua Tentang Tasawuf, Terjemahan Abd Hadi WM., Bandung Mizan, 1973.

Majallah Wanita. "Kartini”, No2129; Edisi 23 Desember 2004 s/d 6 Januari 2005

Al-Marbawi, Muhammad Idris; Kamus Idris al-Marbawiy; Arab Melayu, Kairo Dar al-Fikr. T.tp, t.th.

Al-Munajjid, Muhammad bin Saleh. Silsilah A'mal Al-Qulub, Alih Bahasa oleh Bahrun Abu bakar Ihzan Zubaidi, Lc. Bandung Irsyad Bait al-Salam (IBS), 2006.

Munawir, Ahmad Warson; Al-Munawwir, Kamus Arab Indonesia, Jakarta: Pustaka Progresif, 1984.

Nasr, Sayyed Hossein. Sufi Essays Great Britian: Unwin Paperbacks, 1972.

Nasution, Harun. Islam Rasional; Gagasan dan Pemikiran, Bandung : Mizan, 1998.

-------Islam Ditinjau Dari Berbagai Aspeknya, Jilid I,II, Jakarta: Bulan Bintang, 1994.

'Odea, Thomas F. Sosiologi Agama;Suatu Pengenalan Awal, Penerjemahan Yasogama, Jakarta: Rajawali Press,1996.

Qardhawi, Yusuf. Fiqhi Minoritas Fatwa Kontemporer terhadap kehidupan Kaum Muslimin di Tengah Masyarakat Non Muslim, Jakarta : Zikrul Hakim, 2004.

Qudamah, Ibnu. Mukhtasar Minhajul Qashidin; Jalan orang-orang yang mendapat petunjuk Jakarta Pustaka al-Kautsar, 1997.

Al-Sarraj, Abu Nashr. al-Luma; (ed) Abdul Halim Mahmud dan thaha Abdul Baqi Surur kairo: Maktabah Tsaqifah al-Diniyah, t.th.

Schimel, Annimare. Dimensi Mistik Dalam Islam, terjemah Sapardi Djoko Damono at. al., Jakarta: Pustaka Firdaus,2000.

Shihab, M. Quraish. Menjemput Maut; Bekal Perjalanan Menuju Allah SWT, Jakarta: Lentera Hati, 2002.

-----.Membumikan Al-Quran Fungsi dan Peran Wahyu dalam Kehidupan, Bandung: Mizan1994.

-----Menabur Pesan Ilahi; Al-Quran Dan dinamika Kehidupan Masyarakat, Jakarta : Lentera Hati, 2006. 
-----Mukjizat Al-Qur'an; Ditinjau dari aspek Kebahasaan, Isyarat Ilmiah, dan Pemberitaan Gaib Bandung; Mizan, 2002.

------.Logika Agama: Kedudukan Wahyu dan Batas-batas Akal dalam Islam Jakarta Lentera Hati, 2005.

Ya’qub, Hamsah. Tingkat ketenagan dan kebahagiaan Mukmin; Tasawuf dan Taqarrub, Jakarta: Pustaka Atisa, 1992.

Zakaria, Abi Al-Husain Ahmad bin Faris bin. Al-Mu'jam Maqayis al-lugah, Juz I, Kairo Dar Al-Fikr, 395 H. 